\title{
The Role of Indonesian Disability Entrepreneurial Empowerment on Product Quality and its Impact on Community Trust
}

\author{
Agus Setyo Pranowo, Suryana, Disman
}

\begin{abstract}
In Indonesia, people with disabilities continue to increase, based on quotes from www.kemsos.go.id, the highest number of people with disabilities is in West Java Province (50.90\%). Of the age group, ages 18-60 years occupy the highest position. The most experienced disabilities were leg defects (21.86\%), mental retardation (15.41\%) and speech (13.08\%). Referring to the results of a study from the UB Disability Study and Service Center 2017, there were 1,835 people with disabilities in the city of Bandung who needed empowerment by both the government and non-governmental organizations. Empowerment is important to increase the self-confidence of persons with disabilities and a shift in social stigma towards disability, public trust plays an important role in building opportunities to work and work for disabilities the same as a non-governmental organization. This study examines how the quality can influence trust with product quality as a moderating variable, the approach used is quantitative, and the method used is descriptive with datacollected by observing many subjects at the same point of time, From the populace of 200 consumers taken 67 samples using the Slovin formula, respondents taken were respondents who had bought disability products and were domiciled in Bandung, West Java. This study was tested using PLS Method run by XLSTAT software.
\end{abstract}

Index Terms: Disability, Entrepreneur, Product Quality, Trust, Empowerment.

\section{INTRODUCTION}

In an effort to protect, respect, advance, and fulfill the privileges of people with inabilities, the authority of Indonesia has established various laws and regulations that regulate the protection of persons with disabilities, including Law Number 36 of 2009 concerning Health which covers Elderly Health and Persons with Disabilities in Part Three, namely articles 138-140. According to the Convention on the Rights of Persons with Disabilities, inability is a developing idea, where individuals with impairments fuse the people who have physical, mental, insightful, or material impediments for quite a while and when looked with different deterrents, this can block full investment and their viability in the public eye based on equality with others. The emergence of disability can be motivated by health problems that arise from birth, chronic diseases and economic problems, and injuries that can be caused by accidents, war,

Revised Manuscript Received on September 22, 2019

Agus Setyo Pranowo, Missing Affiliation and email.

Suryana, Missing Affiliation and email.

Disman, Missing Affiliation and email. riots, disasters, and so on. As the elderly population increases, it is suspected that it will increase the number of persons with disabilities due to increased health problems due to chronic degenerative diseases.

In 2016 Mata Hati Indonesia, a nonprofit organization in Bandung Indonesia gathered several disabilities who had a strong motivation to work, through a program called "DPK" they were given soft skills in various production processes, including food and craft products. In this program there are several obstacles, from the results of observations in the field, the main obstacle to DPK products is the community's trust in product quality, social stigma still not fully lost that the products with disabilities that are not labeled (branded) and no quality assurance (certification) consumed. This is consistent with previous research by Rimawan et All (2017) conclude it is significant further, for various factors other than quality things, organization and trust that accentuate consumer loyalty also unwaveringness clients, for example, contenders and contenders intensity in value terms might be considered. This also supports Kotler and Armstrong (2012), brands have the meaning as a name, term, sign, picture, or structure or a blend of them, which hopes to recognize the product or organizations delivered by the maker. As per him, the brand will make it simpler for shoppers to distinguish items that are available, identify which products have more benefits, or which products are in accordance with consumer tastes. Moreover, the brand also states something about consistency and quality. This means that if the quality and consistency of a brand are good, it will be very easily accepted by consumers.

The results of observations in the field also support the theory put forward by Delgado et al. (2005) that the philosophy of building a brand is intended to build market confidence in an offer, trust is a key factor that influences long-term relationships with consumers, especially when facing purchasing decisions that have risky and expensive choices. In this case, the products produced by DPK are products that are at risk, because they are produced by a disabled person, therefore a strong brand needs to be built, one of which is the inclusion of product certification. Regarding the result of observation and the previous research, the author wants to look at the impact of entrepreneurial strengthening on item quality to community trust in DPK community Bandung, Indonesia. 


\section{LITERATURE REVIEW}

\section{A. Entrepreneur}

Enterprise and a private company are connected however positively not synonymous ideas. From one perspective, the business enterprise is a kind of conduct focusing on circumstances instead of assets (Stevenson and Gumpert, 1991). This kind of conduct can occur in both little and expansive organizations yet additionally somewhere else. On the other hand, autonomous experiences can be a vehicle both for Schumpeterian specialists showing new things and procedure that change the business and for individuals who essentially run and have a business expertly (Wennekers and Thurik, 1999). The last assembling joins various franchisees, specialists and people in master occupations. They have a spot with what Kirchhoff (1994) calls "the money related focus". That both venture and privately owned businesses matter is unquestionably not another recognition.

\section{B. Product Quality (Certification)}

Products are intended for satisfaction with the needs and desires of consumers. Manufacturers must pay careful attention to the policies on their products. Basically, a product can be classified in various ways, among others, based on the durability of the product in its use or form of the product. Based on these criteria FandyTjiptono (2002: 5), grouping products into three groups, namely: 1) Non-durable goods (goods that are not too long), namely goods consumed once or have a period of less than one year. 2) Durable goods, ie goods that are durable and can be used for more than one year. 3) Service which is an activity, benefit or satisfaction offered by a company for sale.According to Stanton in Buchari Alma (2000: 20) "Product is a set of attributes, both tangible and non-tangible, including color problems, prices, factory good name, company reputation and service and retailer services received by buyers to satisfy their desires".

Companies will consistently to fullfill clients needs. Quality products are products that have benefits for the wearer (consumers). If someone imagines a product, they imagine the benefits that will be obtained from the product they will use. The benefits in a product are the consequences that consumers expect when they buy and use a product. Many definitions expressed by economists. According to Kotler (2000: 347), "Product quality is a characteristic and characteristic of an item or service that affects its ability to satisfy expressed or implied needs". Komarrudin (1999: 253), defines the quality of products as follows: the ability to use (fitness for use), class or grade (grade), quality of conformance, quality characteristics, quality function and the name of a part in the organization (quality department). The quality of a product is the level of good or bad which consists of all factors inherent in goods or services so that the goods have the ability to be used as desired by the consumers of these products. According to the National Certification Agency in the ISO / IEC 17067: 2013 Standardization Scheme, item affirmation is a similarity evaluation movement that is built to provide the trust of consumer prerequisites, including members, regulators, industry and other interested parties that the item meets specified requirements, including for example execution, security, interoperability, and reasonable products in the territory of Indonesia, conformity to the Indonesian National Standards.

\section{Brand Trust}

Definition trust in this study refers to trust in a brand from a prospective community. As per Murthy (in Kertajaya, 2009: 11) in point view of-ofthe organization, brand trust is a brand that effectively makes vital brand encounters in customers that are reasonable in the long haul, in view of the respectability, genuineness, and affableness of the brand. As per Guviez and Korchia (in Ferinnadewi, 2008: 148) from the perspective of buyers, brand trust is a mental variable that mirrors various starting suppositions including validity, uprightness, and altruism, which are connected to specific brands. The brand trust will influence consumer loyalty and client dependability. Thinking about this, brand trust has a vital job for the item. As per the feeling of Delgado, (in Ferinnadewi, 2008: 150) brand trust is the expectation of good brand unwavering quality and aim. In view of this definition brand trust reflects two imperative segments, the first is, buyer certainty that the item can meet the guaranteed esteem or at the end of the day the recognition that the brand can meet purchaser desires by satisfying the brand guarantee that at last makes consumer loyalty, the second, customer certainty that the brand can organize the interests of buyers when issues in item utilization show up suddenly.

As indicated by Delgado (in Ferinnadewi, 2008: 150) brand trust is the expectation of brand unwavering quality and well-meaning plans since that brand trust reflects two things in particular brand dependability and brand intentions: 1) Brand dependability or brand unwavering quality that originates from purchaser certainty that the item can meet the guaranteed esteem or at the end of the day the observation that the brand can address issues and give fulfillment. Brand unwavering quality is fundamental for the formation of trust in the brand in light of the way that the capacity of the brand to satisfy the guaranteed esteem will comprehend trust in getting what is required for this situation the need to escape feeling compromised. 2) Brand expectation depends on purchaser certainty that the brand can organize the interests of shoppers when issues in item utilization show up suddenly. The two segments of brand trust depend on emotional buyer judgment or dependent on the view of every purchaser of the advantages that the item/brand can give.

\section{Disability}

According to the Big Dictionary of Indonesian Language 1 , the person is interpreted as someone who is suffering from something. Whereas disability is an Indonesian word derived from disability English (plural: disabilities) which means disability or disability. According to Law Number 19 Year 2011 concerning 
Ratification of the Privileges of Persons with Disabilities, in particular individuals who have physical, mental, scholarly or tactile limitations for a long period of time who interact with the environment and the attitudes of their people can encounter obstacles that make it difficult to participate fully and effective based on equality of rights. 2 Law Number 4 of 1997 concerning Persons with Disabilities in the main point of the opening point 1 (first) convention provides understanding, namely; Any person who has a physical and / or mental disorder, which can interfere with or constitute a hindrance and relationship for him to do appropriately, consisting of, physically disabled persons; mentally disabled people; physically and mentally disabled.

\section{E. Empowerment}

By and large empowering is characterized as a multi-dimensional social procedure that causes individuals to manage their very own lives. Richard Carver, Managing Director of Coverdale Organization, characterizes strengthening as urging and enabling somebody to assume individual liability to enhance or enhance approaches to finish work so they can add to accomplishing hierarchical objectives. Strengthening requires the making of a culture that energizes workers at all dimensions to accomplish something else and encourages representatives to be certain and ready to make changes. Notwithstanding the comprehension passed on by Carver (1994), there are a few different understandings about strengthening. In any case, every one of the definitions that exist on a basic level share for all intents and purpose, specifically that strengthening contains the accompanying components: Right off the bat, there is devolution of power and obligation regarding settling on choices that are bolstered by satisfactory assets. A short time later, there is power over the designation of power from the board. There is a formation of a domain with the goal that workers can take advantage of their capacities or capabilities to accomplish authoritative objectives. Strengthening object is a condition experienced by the network which is described by the capacity to think, choose and accomplish something that is considered proper so as to accomplish the arrangement of the issues looked by utilizing power.

\section{F. Research Framework}

A strong brand will give the image, knowledge and brand awareness in the minds of consumers and make them believe in the products or services offered, good product quality will also affect consumers to trust the brand of the product. In business, the conviction is viewed as a standout amongst the most steady and stable helpful connections. Morgan and Hunt (1994) express that convictions exist just when one gathering has certainty in the trading of organizations and globally. As indicated by Mayer et al. (1995) Factors that makeup one's trust in different items are three to be specific (capacity), consideration (altruism), and trustworthiness (honesty).According to Morgan (2000: 76), from the company side, through strong brands, organizations can deal with their benefits well, increment income, grow a piece of the overall industry, set premium costs, decrease advancement costs, increment deals, look after steadiness, and improve upper hand. Based on the literature review, the research framework is arranged in the following figure:

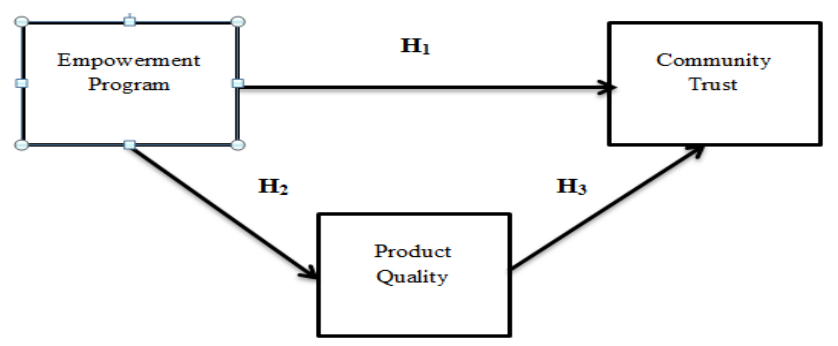

Fig. 1: Research Framework and Hypothesis

Table 1. Research Hypothesis

\begin{tabular}{|cl|}
\hline $\mathrm{N}_{0}$ & \multicolumn{1}{c|}{ Hypothesis } \\
\hline $\mathrm{H}_{1}$ & Entrepreneurial Empowermentinfluenceon Community Trust \\
\hline $\mathrm{H}_{2}$ & Entrepreneurial Empowerment influence on Community Trust Through Product Quality \\
\hline $\mathrm{H}_{3}$ & Product Quality influence Community Trust. \\
\hline
\end{tabular}

With the provision of:

1. $\mathrm{t}$ arithmetic $>\mathrm{t}$ table $=\mathrm{Ho}$ is do not accepted and $\mathrm{H}_{1}$ accepted.

2. $\mathrm{t}$ arithmetic $<\mathrm{t}$ table $=$ Ho accepted and $\mathrm{H}_{1}$ is do not accepted.

\section{METHODOLOGY}

The type of research conducted by researchers is descriptive research. Descriptive research is research whose main purpose is to describe something, usually in the form of market characteristics or functions (Malhotra, 2010: 106). The research conducted seeks to find out and analyze the influence of Disability entrepreneurial empowerment program on community trust through product quality. This study is a single cross-sectional design, which is a study conducted once during one period (Malhotra, 2010: 108). Data collection is done by questionnaire survey techniques to respondents who are domiciled in the Bandung area and who have purchased DPK products. Data will be processed using statistical methods using XLSTAT software.In determining the number of sample members the researcher sets out the average population of buyers for the past 1 (one) year as many as 200, then the data is processed using the sampling technique according to Taro Yamane quoted by Hamdi (2010: 131) with Slovin formula as follows:

$$
n=\frac{N}{N \cdot d^{2}+1}
$$

Where:

$\mathrm{n}=$ number of samples

$\mathrm{N}=$ number of population $=200$

d2 = precision (set at $10 \%$ and $90 \%$ confidence level)

Based on the formula obtained the number of samples as follows:

$$
\begin{aligned}
& \mathrm{n}=200 \\
& {[200(0,1) 2+1]} \\
& =107,675 / 1077.75 \\
& \mathrm{n}=66.67=67 \text { (rounded up) } \\
& \text { In this study the sampling }
\end{aligned}
$$


technique used is non probability sampling with accidental sampling technique is a technique of determining samples based on chance, that is, anyone who accidentally met with a researcher could be used as a sample, if viewed by the person who happened to be found suitable as a data source (Sugiyono, 2001: 60).

The data used to build this research are primary data and secondary data. Primary data is data originating from researchers, collected by researchers to deal with a research problem encountered which is obtained from the results of observations and questionnaires. Meanwhile, secondary data is pre-existing data, which has been collected to solve research problems, secondary data in this study is the study of literature and consumer databases of DPK itself.

\section{RESULt}

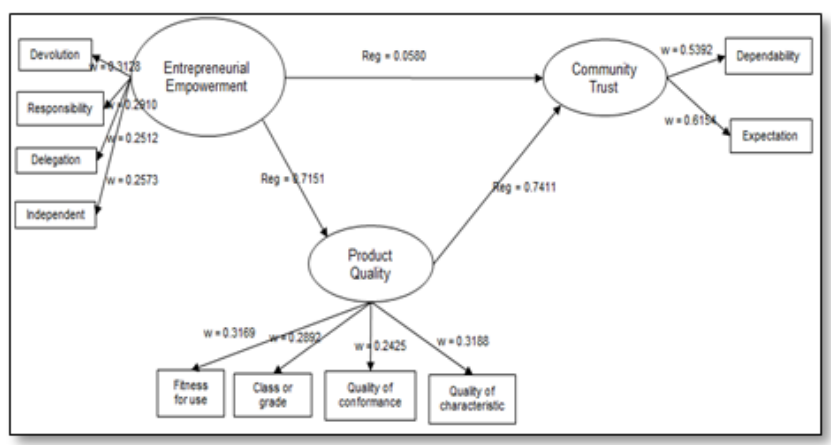

Fig. 2 Hypothesis Testing With XLSTAT

\section{A. Outer Model Test}

Table 2. Cross Loading

\begin{tabular}{|l|c|c|c|}
\hline & $\begin{array}{c}\text { Entrepreneurial } \\
\text { Empowerment }\end{array}$ & $\begin{array}{c}\text { Product } \\
\text { Quality }\end{array}$ & $\begin{array}{c}\text { Community } \\
\text { Trust }\end{array}$ \\
\hline Devolution & $\mathbf{0 . 9 1 9 7}$ & 0.7198 & 0.5875 \\
\hline Responsibility & $\mathbf{0 . 8 5 8 5}$ & 0.5993 & 0.6165 \\
\hline Delegation & $\mathbf{0 . 9 1 0 1}$ & 0.6227 & 0.4272 \\
\hline Independent & $\mathbf{0 . 9 0 8 8}$ & 0.6183 & 0.4568 \\
\hline Fitness for use & 0.7645 & $\mathbf{0 . 8 6 9 5}$ & 0.6133 \\
\hline Class or grade & 0.6311 & $\mathbf{0 . 8 8 8 1}$ & 0.6259 \\
\hline $\begin{array}{l}\text { Quality of } \\
\text { conformance }\end{array}$ & 0.4040 & $\mathbf{0 . 7 7 1 6}$ & 0.6502 \\
\hline $\begin{array}{l}\text { Quality of } \\
\text { characteristic }\end{array}$ & 0.6033 & $\mathbf{0 . 8 7 9 8}$ & 0.7828 \\
\hline Dependability & 0.4997 & 0.7603 & $\mathbf{0 . 8 8 4 0}$ \\
\hline Expectation & 0.5203 & 0.5837 & $\mathbf{0 . 8 4 5 8}$ \\
\hline
\end{tabular}

Source: Data Run with XLSTAT (2019)

In Table 2, the results of data processing from questionnaires using XLSTAT software indicate the indicator in convergent validity value of each variable has a factor loading more than 0.50 means the statement in the questionnaire valid and can represent the variables in this study, the higher the factor loading the higher the validity.

Table 3. Discriminant Validity ( AVE)

\begin{tabular}{|l|c|c|c|r|}
\hline & $\begin{array}{c}\text { Entrepreneurial } \\
\text { Empowerment }\end{array}$ & $\begin{array}{c}\text { Product } \\
\text { Quality }\end{array}$ & $\begin{array}{c}\text { Community } \\
\text { Trust }\end{array}$ & $\begin{array}{c}\text { Mean } \\
\text { Communalities } \\
\text { (AVE) }\end{array}$ \\
\hline Entrepreneurial Empowerment & $\mathbf{1}$ & 0.5114 & 0.3458 & 0.8092 \\
\hline Product Quality & 0.5114 & 1 & 0.6125 & 0.7285 \\
\hline Community Trust & 0.3458 & 0.6125 & $\mathbf{1}$ & 0.7484 \\
\hline Mean Communalities (AVE) & 0.8092 & 0.7285 & 0.7484 & $\mathbf{0}$ \\
\hline
\end{tabular}

Source: Data Run with XLSTAT (2019)

Table 3shows that all variables are Entrepreneurial
Empowerment (X1),Product Quality (Y), and Community Trust (Z) have AVE values and Communality greater than 0.5 . This shows that the overall variable has met the criteria of discriminant validity. So that it can be stated that the question items are valid in measuring the variable.

Table 4. Composite Reliability

\begin{tabular}{|l|c|c|c|}
\hline \multicolumn{1}{|c|}{ Latent variable } & Dimensions & Cronbach's alpha & $\begin{array}{c}\text { D.G. rho } \\
\text { (PCA) }\end{array}$ \\
\hline Entrepreneurial Empowerment & 4 & 0.9214 & 0.9446 \\
\hline Product Quality & 4 & 0.8752 & 0.9148 \\
\hline Community Trust & 2 & 0.6650 & 0.8565 \\
\hline
\end{tabular}

Source: Data Run with XLSTAT (2019)

According to Table 4, the results of data processing from questionnaires using XLSTAT software indicate that construct of each variable has a Cronbach Alpha more than 0.60 means the statement in the questionnaire reliable and can represent the variables of entrepreneurial empowerment, product quality and community trust in this study.

\section{B. Inner Model Evaluation}

Table 5. The goodness of fit index

\begin{tabular}{|l|c|c|c|r|}
\hline & GoF & $\begin{array}{c}\text { GoF } \\
\text { (Bootstrap) }\end{array}$ & $\begin{array}{c}\text { Standard } \\
\text { error }\end{array}$ & $\begin{array}{c}\text { Critical ratio } \\
\text { (CR) }\end{array}$ \\
\hline Absolute & 0.6561 & 0.6561 & 0.1109 & 5.9164 \\
\hline Relative & 0.8775 & 0.8466 & 0.1037 & 8.4609 \\
\hline Outer model & 0.9923 & 0.9782 & 0.0840 & 11.8089 \\
\hline Inner model & 0.8843 & 0.8633 & 0.0445 & 19.8768 \\
\hline
\end{tabular}

ource: Data Run with XLSTAT (2019)

The GoF value of 0.8633 means that the diversity of data can be explained by the model this is $86.3 \%$ or in other words, the information contained in the data is $86.33 \%$ can be explained by the model. While the remaining $13.67 \%$ is explained by other variables outside the model used in this study.

Table 6. Direct Influence

\begin{tabular}{|c|l|c|c|c|c|c|}
\hline Hypothesis & \multicolumn{1}{|c|}{ Influence } & $\begin{array}{c}\text { Path } \\
\text { Coefficients }\end{array}$ & t-test & t-table & Pr $|t| t \mid$ & Result \\
\hline$H_{1}$ & $\begin{array}{l}\text { Entrepreneurial Empowerment } \rightarrow \\
\text { Community Trust }\end{array}$ & 0.0580 & 0.5305 & 1.99 & 0.5976 & $\begin{array}{c}\text { Not } \\
\text { Accepted }\end{array}$ \\
\hline $\mathrm{H}_{3}$ & Product Quality $\rightarrow$ Community Trust & 0.7411 & 6.7757 & 1.99 & 0.0000 & Accepted \\
\hline
\end{tabular}

Source: Data Run with XLSTAT (2019)

The level of significance is obtained by comparing the count with $\mathrm{t}$-table value. If the value of $\mathrm{t}$-count is greater than $\mathrm{t}$-table, the relationship between these variables is significant. The amount of data is 67 , then the t-table value $(\alpha=5 \%)$ is 1.99 the results of the relationship between variables are presented in Table 5 above. Only hypothesis 1 that not accepted because $\mathrm{t}$ table is greater than $\mathrm{t}$ tested. Entrepreneurial empowerment not directly influenceon disability product in Bandung city. Result for indirect influence shown in table 7 below:

Table 7. Indirect Influence

\begin{tabular}{|c|c|c|c|c|c|c|}
\hline Hypothesis & Variable & Variable & Intervening & T-test & \multicolumn{2}{|c|}{ Influence } \\
\cline { 5 - 7 } & Exogenous & Endogenous & Variable & & Direct & Indirect \\
\hline $\mathrm{H}_{2}$ & Entrepreneurial & Community & $\begin{array}{c}\text { Product } \\
\text { Qunality }\end{array}$ & 8.3742 & 0.0580 & $0.0580 \times 0.7411=$ \\
& Empowerment & Trust & & & $\mathbf{0 . 0 4 2 9 8}$ \\
\hline
\end{tabular}

Source: Data Run with XLSTAT (2019)

Published By: Blue Eyes Intelligence Engineering \& Sciences Publication 
Data in table 7 shown above indicate entrepreneurial empowerment variables indirectly influence community trust through product quality, the t-test value also is shown significance, the t-test is greater than t-table.

\section{Discussion}

Result from this examination obviously bolster look into Cronin et al (2000) that gets that quality influences the esteem recognition and consumer loyalty, and furthermore specifically impacts customer conduct. In this investigation, the quality items likewise influence dependability clients. This is congruent with Kumar et al (2011) explore, poor working execution on quality viewpoints that have a negative and direct effect on client reliability, and Jahanshahi et al (2011) look into, client devotion is generally in the classification of clients who have utilized the Product High-quality items. Whenever broke down through the feeling of valuable items as indicated by Kotler and Amstrong (2001) which expresses that quality items are the capacities of the item in showing its capacities, it incorporates item helpfulness, unwavering quality, convenience and fix and different qualities. This result also inline with Noorizan and Abdullah (2011) takes a gander at the convictions as the client duty relationship. They found that trust had a positive and noteworthy effect on duty connections. These discoveries demonstrate that clients keep uplong haul contracts with their specialist organizations, the trust will conceivably be the main impetus of client responsibility or solid steadfastness.

\section{Conclusion}

Empowering program and product quality is not the ones that influence dependability and expectationcommunity in disability SMEs. There are probably going to be factors other than product quality and empowering program. In this case, disabled that able to fulfill expectation and dependability from the consumer can gain their trust, different to empowering program cannot directly influence consumer trust, there are moderating variables that can higher the possibility trust which is product quality. Due to result, private sector or government can collaborate in increasing product quality that produces by disabled in Bandung city, after the empowering they need to certificated quality for proof that their product has meet consumer expectation and regulation of quality standard so the business can exist longer.

\section{REFERENCES}

[1] Aaker, David. A (1997), ManajemenEkuitasMerek.MemanfaatkanNilai Dari SuatuMerek, MitraUtama, Jakarta.

[2] Armstrong, Garry \& Philip Kotler. Marketing an Introduction (Eight Edition). New Jersey: Pearson Prentice Hall. 2007.

[3] Ali, Hasan. 2013. Marketing danKasus-KasusPilihan. Yogyakarta.CAPS (Center for Academic Publishing Service).

[4] Buchari Alma, ManajemenPemasarandanPemasaranJasa.PenerbitAlfabet, Bandung.

[5] Carver, R. 1994. The power of empowerment David Clutterbuck and Susan Kernaghan BCA/Kogan 256 pages.

[6] Cronin, J. Joseph Jr., Brady, Michael. K., Hult, G. Tomas.M. (2000). Assessing the Effects of Quality, Value, and Customer Satisfaction on
Consumer Behavioral Intentions in Service Environments. Journal of Retailing, 76(2).

[7] Delgado M. R., Frank R. H., Phelps E. A. (2005a). Perceptions of Moral Character Modulate the Neural Systems of Reward During the Trust Game. Nat. Neurosci. 8, 1611-161810.1038/nn1575.

[8] FandyTjiptono, 2002, ManajemenJasa, PenerbitAndi Yogyakarta.

[9] Gede Riana, "Pengaruh Trust in a Brand terhadap Brand Loyalty padaKonsumen Air Minum Aqua di Kota Denpasar", BuletinStudiEkonomi Volume 13 Nomor 2 Tahun 2008.

[10] Jahanshahi, A. A., Gashti, M. Ali H., Mirdamadi, S. A., Nawaser, Khaled.,Khaksar, Seyed M.S. (2011). Study the Effects of Customer Service and Product Quality on Customer Satisfaction and Loyalty. International Journal of Humanities and Social Science, 1(7).

[11] Keller, K. L 2003, Strategic Brand Management: Building, Measuring, and Managing Brand Equity, 2nd Edition, Upper Saddle River (N.J.), Pearson Prentice Hall.

[12] Keller, K.L. (2003). Strategic Brand Management, 2nd ed., Prentice Hall, New Jersey.

[13] Kumar, Vikas., Luciano., Maull, Roger. (2011). The Impact of Operations Performance on Customer Loyalty. Service Science, 3(2).

[14] Lasser, W., Mittal, B. andSharrna, A.(1995)."Measuring Costumer-Based Brand Equity", Journal of Consumer Marketing, Vol.12, No.4.

[15] Morgan, R.M., \& Hunt, S. D. (1994).The commitment-trust theory of Relationship Marketing.Journal of Marketing, 58.

[16] Norizan, Kassim., Abdullah, N.A.(2010). The effect of perceived service quality dimensions on customer satisfaction, trust, and loyalty in e-commerce settings A cross-cultural analysis. Asia Pacific Journal of Marketing and Logistics, 22

[17] Rimawan, K.et al.2017.The Influence of Product Quality, Service Quality, and Trust on Customer Satisfaction and Its Impact on Customer Loyalty (Case Study PT ABC Tbk). International Journal of Scientific \& Engineering Research Volume 8, Issue 7, July-2017.

[18] Thurik, R; Sander W. 2004.Entrepreneurship, small business, and economic growth.Journal of Small Business and Enterprise Development; 11, 1; ABI/INFORM Global pg. 140

\section{AUTHORS PROFILE}

Agus Setyo Pranowo.my area of interest is social science and community development

Suryana, my area of interest is social science and community development

Disman, my area of interest is social science and community development 